\title{
Evaluation of TS 825 Thermal Insulation Requirements in Buildings in Turkey in Terms of Solar Radiation
}

\author{
TS 825 Binalarda Isı Yalıtım Kuralları Standardının \\ Güneş Işınımı Açısından Değerlendirilmesi
}

\section{Betül BEKTAŞ EKICi}

\section{ABSTRACT}

TS 825 Thermal Insulation Requirements in Buildings, the obligatory standard, is still in effect, and is used to calculate the heating energy requirements of buildings in Turkey. The total solar heat gain through windows is calculated using the solar radiation table given in Appendix-C of TS 825. Although Turkey is divided into four different degree day regions according to this standard, Appendix-C offers the same solar radiation data for all regions. This study aimed to investigate the appropriateness of the Appendix- $\mathrm{C}$ table for the different degree day regions. The hourly solar radiation on the vertical surfaces of a building envelope was calculated for 16 selected cities. Long-term sunshine duration data for each location were obtained from the Turkish State Meteorological Service. It is demonstrated that the solar radiation table given in Appendix-C of TS 825 is not appropriate for the four degree day regions. The calculated solar radiation values of the cities are considerably different from the table values, with the ratios varying between $3.03 \%$ and $69.15 \%$ for horizontal surfaces, $0.171 \%$ and $53.29 \%$ for south, $0.25 \%$ and $22.15 \%$ for north and $0.60 \%$ and $40.42 \%$ for east and west oriented surfaces.

\section{ÖZET}

TS 825 Binalarda İsi Yalıtım Kuralları Standardı (zorunlu standart) Türkiye'de binaların ısıtma enerjisi ihtiyaçlarının hesaplanmasında halen kullanılmaktadır. Pencerelerden olan güneş ISISı kazançları TS 825 EK-C'de verilen güneşışınımı tablosu ile hesaplanmaktadır. Bu standarda göre Türkiye dört farklı derece gün bölgesine ayrılmış olmasına rağmen EK-C her bölge için aynı güneş ışınımı verilerini önermektedir. Bu çalışma EK-C tablosunun farklı derece gün bölgeleri için uygunluğunu değerlendirmeyi amaçlamaktadır. Bina kabuğunun düşey yüzeyleri üzerindeki saatlik güneşışınımı değerlerini seçilmiş 16 şehir için hesaplamıştır. Her bir yerleşim yerine ait uzun yıllar günlük güneşlenme süresi verisi Devlet Meteoroloji işleri Genel Müdürlüğü'nden temin edilmiştir. Sonuç olarak, TS 825 EK-C'de verilen güneş ışınımı tablosunun dört derece gün bölgesi için de uygun olmadığı kanıtlanmıştır. Şehirler için hesaplanan güneşışınımı değerlerinin yatay yüzeyler için \%3.03 ve \%69.15, güney için \%0.171ve $\% 53.29$, kuzey için \%0.25 ve \%22.15 ve doğu ve bat yönleri için \%0.60 ve \%40.42 arasında değişen önemli oranlarda farklılıklar göstermektedir.

Department of Architecture, Firat University Faculty of Architecture, Elazığ, Turkey.

Fırat Üniversitesi, Mimarlık Fakültesi, Mimarlık Bölümü, Elazığ.

Article arrival date: March 12, 2014 (Başvuru tarihi: 12 Mart 2014) - Accepted for publication: November 13, 2014 (Kabul tarihi: 13 Kasım 2014)

Correspondence (iletişim): Betül BEKTAŞ EKiCi. e-mail (e-posta): betulbektas80@gmail.com

๑ 2015 Yıldız Teknik Üniversitesi Mimarlık Fakültesi - ๑ 2015 Yıldız Technical University, Faculty of Architecture 


\section{Introduction}

Solar radiation is vital data for architects, engineers and scientist not only for the development of active solar energy systems but also for providing energy efficiency in buildings. ${ }^{[1]}$ This renewable source has the biggest contribution to the energy balance of buildings during the daytime. ${ }^{[2]}$ The indoor thermal environment is directly affected by the solar heat gains through glazed areas of the building envelope. ${ }^{[3]}$ Reliable data for any particular location is needed for optimization and performance evaluation of buildings and solar technologies.

Due to its geographical position between $36^{\circ}$ and $42^{\circ}$ latitudes, Turkey has a big solar energy potential and an opportunity to benefit from this endless energy source in building design, developing renewable energy technologies, agriculture and many other applications. ${ }^{[4]}$ In Turkey, the global solar radiation on horizontal surfaces has been measured at most of the meteorological stations. The required solar radiation data for passive utilization in building design is the intensity of the solar radiation on vertical surfaces. However, the solar radiations on the vertical surfaces of building envelope have not been measured except by a few research projects in some limited locations. ${ }^{[5-7]}$ Because of this deficiency, some table values (such as TS $825,{ }^{[8]}$ ASHRAE $^{[9]}$ etc.) of solar radiation are generally used while calculating the solar heat gains of windows for determining buildings energy needs.

Nowadays large glazed vertical surfaces play an important role in determining the thermal performance of buildings. If there were no precautionary measures taken, this situation causes big heat losses from glazed surfaces due to the high thermal conductivity in winter and cooling problems related to the excessive solar gains in summer. This fact necessitates the careful usage of this important facade component. Windows are very important because they can act as a beneficial heat source if they are placed in the correct directions towards the sun. Thus, their effect on a building's heat balance (especially solar heat gain) must be determined accurately.

In Turkey, there are two main regulations in effect. They are used for determining the energy requirements of buildings. The first one, Energy Performance Regulation in Buildings ${ }^{[10]}$ proposes the calculation of instantaneous solar radiation on building surfaces while determining the building's energy needs. The second one, TS 825 Thermal Insulation Requirements in Buildings is mandatory and widely used for calcu- lating heating energy needs of buildings. According to this standard, Turkey is divided into four degree day regions (DDR).

In the literature, there are many studies performed on TS 825. Dilmac and Kesen ${ }^{[11]}$ described the revised TS 825 Turkish Standard and compared TS 825 with the ISO9164, EN 832 and German Regulations. They noted that the calculation method of internal heat gains, the calculation method of solar gains, the acceptance of the air change rate values and climatic data are the main differences between the standards. Generally, the other previous studies performed on TS 825 were based on determination of optimum insulation thicknesses for different degree day regions. ${ }^{[12-17]}$ Aksoy and Bektaş Ekici ${ }^{[5]}$ investigated the appropriateness of climatic data given in TS 825 for different DDRs with different building samples.

The studies performed on determining the solar radiation potential of a location are independent from TS 825. Bulut and Büyükalaca ${ }^{[18]}$ developed a simple model for predicting the daily global solar radiation for 68 provinces of Turkey. The accuracy of the model was tested with the measured solar radiation data recorded at meteorological stations of each province. Bulut et al. ${ }^{[19]}$ evaluated the performances of the different solar radiation calculation methods with the measured solar radiation data for $15^{\circ}, 30^{\circ}, 45^{\circ}, 60^{\circ}$, and $90^{\circ}$ inclined surfaces located in Sanliurfa, Turkey. Togrul et al. ${ }^{[20]}$ investigated the appropriateness of clear sky radiation in forecasting the average global solar radiation both for summer and winter seasons. Senkal and Kuleli ${ }^{[21]}$ employed an artificial neural network in prediction of solar radiation in Turkey. The study was performed on 12 cities by using the meteorological and geographical data of each city. Sozen et al. ${ }^{[4]}$ aimed to calculate the solar potential of Turkey by employing artificial neural network. They used the measured data of 11 meteorological stations for prediction of 6 stations and achieved $99.893 \%$ accuracy.

In this study, four different cities from each of the DDRs were selected randomly. During the selection process it is aimed to choose cities from different geographical regions and located as far as possible from each other. The locations of the selected cities are given in Figure 1 . The hourly solar radiations on building vertical surfaces were calculated with the sunshine duration data of each location taken from Turkish State Meteorological Service. The calculations were carried out with a computer program written in MATLAB. 


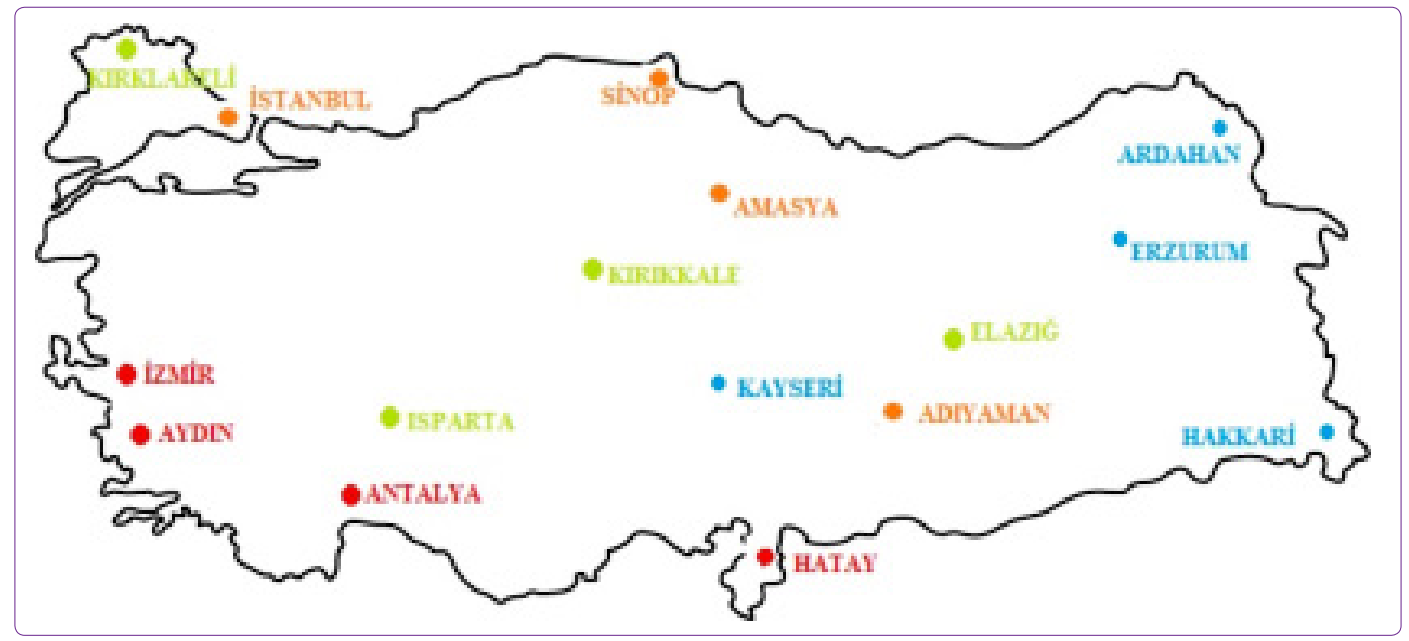

Figure 1. The location of the selected cities for evaluation of Appendix-C.

\section{Calculation of Solar Dadiation On Horizontal and Vertical Surfaces}

\section{Solar radiation on horizontal surfaces}

In literature there are many empirical correlations developed for the determination of solar radiation on horizontal surfaces. ${ }^{[22-26]}$ The equation derived by Angstorm $^{[22]}$ is more practical for Turkey. ${ }^{[27]}$ The ratio of $\mathrm{Q}$, the daily solar radiation on horizontal surface (MJ/ $\mathrm{m}^{2}$-day) to $Q_{0}$, the daily total extraterrestrial solar radiation on horizontal surface $\left(\mathrm{MJ} / \mathrm{m}^{2}\right.$-day) is given with the following equation.

$$
\frac{\mathrm{Q}}{\mathrm{Q}_{0}}=\mathrm{a}+\mathrm{b} \frac{\mathrm{t}}{\mathrm{t}_{\mathrm{d}}}
$$

Where $t$ and $t_{d}$ are the daily sunshine duration and day length in hours respectively. The values for a and $b$ can be obtained with the equations given below. $z$, $\phi$ and $\delta$ are the altitude $(\mathrm{m})$, latitude and declination angles $\left({ }^{\circ}\right)$ respectively.

$$
\begin{aligned}
& a=0.103+0.000017 z+0.198 \cos (\phi-\delta) \\
& b=0.533-0.165 \cos (\phi-\delta)
\end{aligned}
$$

Day length can be calculated by employing declination and latitude angles as given below. The formula for the calculation of declination angle is given in equation 5 . Where $\mathrm{n}$ is the number of the day from $1^{\text {st }}$ January.

$$
\begin{aligned}
& t_{d}=(2 / 15) \arccos (-\tan \delta \tan \phi) \\
& \delta=23.45 \sin \left(360 \frac{284+n}{365}\right)
\end{aligned}
$$

Daily total extraterrestrial solar radiation $\left(Q_{0}\right)$ is calculated by the following expression. $I_{s c}$ and $\omega_{s}$ in the equations are the solar constant $\left(1353 \mathrm{~W} / \mathrm{m}^{2}\right)$, sunrise and sunset angle $\left({ }^{\circ}\right)$ respectively.

$$
\mathrm{Q}_{0}=\frac{24}{\pi} \operatorname{Isc}\left(1+0.033 \cos \left(\frac{360 \mathrm{n}}{365}\right)\right)\left(\cos \delta \cos \phi \sin \omega_{\mathrm{s}}+\frac{\pi}{180} \omega_{\mathrm{s}} \sin \delta \sin \phi\right)
$$

The instantaneous solar radiation on a location can be determined with the Equations 7 and $8 .{ }^{[28]} \omega$ and $\omega s$ in equation 7 and 8 are the solar hour and solar sunset hour angles respectively.

$$
\begin{aligned}
& \frac{\mathrm{I}_{\mathrm{a}}}{\mathrm{Q}}=\frac{\pi}{4 \mathrm{t}_{\mathrm{g}}}=\left(\cos \left(\frac{180 \omega}{2 \omega_{\mathrm{s}}}\right)+\frac{2}{\sqrt{\pi}}(1-\psi)\right) \\
& \psi=\exp \left\{-4\left(1-\frac{|\omega|}{\omega_{\mathrm{s}}}\right)\right\}
\end{aligned}
$$

\section{Solar radiation on vertical surfaces}

While $I_{b, t}, I_{r, t}$ and $I_{d, t}$ are the hourly beam, reflected and diffuse solar radiations on an inclined surface respectively, the amount of total solar radiation on an inclined surface $I_{t}\left(\mathrm{~W} / \mathrm{m}^{2}\right)$ is expressed as; ${ }^{[29-31]}$

$$
I_{t}=I_{b, t}+I_{r, t}+I_{d, t}
$$

The direct component $\left(\mathrm{I}_{\mathrm{b}, \mathrm{t}}\right)$ can be calculated from Equation 10 and the $r_{b}$ parameter is calculated with Equation 11 given below;

$$
\begin{aligned}
& \mathrm{I}_{\mathrm{b}, \mathrm{t}}=\mathrm{I}_{\mathrm{b}} \cdot \mathrm{r}_{\mathrm{b}} \\
& \mathrm{r}_{\mathrm{b}}=\frac{\cos \theta}{\cos \theta_{z}}
\end{aligned}
$$

where $I_{b}$ is the hourly beam solar radiation on $a$ horizontal plane $\left(\mathrm{W} / \mathrm{m}^{2}\right), \theta$ and $\theta_{z}$ are the angles of incidence and zenith $\left({ }^{\circ}\right)$ which can be calculated with 
Equations 12 and 13 respectively. ${ }^{[32]} \beta$ is the angle between horizontal plane and inclined surface, which is $90^{\circ}$ for a vertical wall.

$$
\begin{aligned}
& \cos \theta=\sin \delta \cdot \sin (\phi-\beta)+\cos \delta \cdot \cos (\phi-\beta) \cdot \cos \omega \\
& \cos \theta_{z}=\sin \delta \cdot \sin \phi+\cos \delta \cdot \cos \phi \cdot \cos \omega
\end{aligned}
$$

The hourly reflected radiation $\left(I_{r, t}\right)$ is given in Equation 14. It is assumed that the reflection is considered as isotropic and the reflectance of beam and diffuse radiation are identical. ${ }^{[33]}$

$$
\mathrm{I}_{\mathrm{r}, \mathrm{t}}=\frac{1}{2} \rho \sin ^{2}\left(\frac{\beta}{2}\right)
$$

$\rho$ is the grounds reflection rate and is taken as $0.2^{[34,35]}$ in this study. $I$ is the hourly global solar radiation on a horizontal plane $\left(\mathrm{W} / \mathrm{m}^{2}\right)$.

It is assumed that the diffuse radiation is uniform over the sky dome. Thus the diffuse radiation $\left(I_{d, t}\right)$ is calculated with the following formula. ${ }^{[36]} I_{d}$ in equation (15) is the hourly diffuse solar irradiance on a horizontal plane $\left(\mathrm{W} / \mathrm{m}^{2}\right)$.

$$
I_{d, t}=\frac{1}{2} I_{d}(1+\cos \beta)
$$

\section{Findings and Evaluations}

The presented study is based on a numerical analysis. Using the numerical method explained in Section 2 , the hourly solar radiations on building horizontal and vertical surfaces were calculated with a computer program written in MATLAB. Four different cities from each of the four different DDRs according to TS 825 Thermal Insulation Requirements in Buildings were selected. The calculations were carried out for these 16 cities. The sunshine duration for each city was taken from Turkish State Meteorological Service. Some geographical properties of the selected cities are given in Table 1.

Horizontal glazing is not widely used in residential buildings Turkey. However, it is one of the indispensable lighting elements of shopping centers and atrium buildings. The indoor comfort conditions of these large buildings are directly affected by the usage of horizontal glazing. TS 825 Thermal Insulation Requirements in Buildings suggests the usage of solar radiation data determined for south surfaces.

Horizontal surfaces have the biggest solar potential due to exposure of solar radiation directly during the year. So maximum errors among all directions were detected for these surfaces. The calculated and suggested solar radiations for horizontal surfaces in Figure 2 only converge for January and December. Except these two months, the differences vary between $12.06 \%$ (Hatay) and $67.76 \%$ (izmir) for the $1^{\text {st }}, 2.61 \%$ (Sinop) and $68.33 \%$ (Adıyaman) for the $2^{\text {nd }}, 3.03 \%$ (Kırıkkale) and $68.92 \%$ (Elazığ) for the $3^{\text {rd }}$ and $0.63 \%$ (Ardahan) and $69.15 \%$ (Hakkari) for the $4^{\text {th }}$ DDRs as given in Table 2. The minimum differences between Appendix-

\begin{tabular}{|c|c|c|c|c|}
\hline Degree day region & Provinces & Latitude $\left({ }^{\circ}\right)$ & Longitude $\left({ }^{\circ}\right)$ & Altitude (m) \\
\hline \multirow[t]{4}{*}{$1^{\text {st }} \mathrm{DDR}$} & Antalya ( $\left.1^{\text {st }} z o n e\right)$ & 36.54 & 30.42 & 43 \\
\hline & İzmir (1 $1^{\text {st }}$ zone) & 38.25 & 27.09 & 25 \\
\hline & Hatay ( $1^{\text {st }}$ zone) & 36.52 & 36.12 & 85 \\
\hline & Aydın ( $1^{\text {st }}$ zone $)$ & 37.51 & 27.51 & 70 \\
\hline \multirow[t]{4}{*}{$2^{\text {nd }} \mathrm{DDR}$} & İstanbul ( $\left.2^{\text {nd }} z o n e\right)$ & 41.01 & 28.58 & 30 \\
\hline & Amasya ( $\left.2^{\text {nd }} z o n e\right)$ & 40.40 & 35.50 & 392 \\
\hline & Sinop ( $\left.2^{\text {nd }} z o n e\right)$ & 42.01 & 35.09 & 32 \\
\hline & Adıyaman ( $2^{\text {nd }}$ zone $)$ & 37.46 & 38.17 & 669 \\
\hline \multirow[t]{4}{*}{$3^{\text {rd }}$ DDR } & Elazığ ( $3^{\text {rd }}$ zone) & 38.41 & 39.14 & 1015 \\
\hline & Kırıkkale ( $3^{\text {rd }}$ zone) & 39.50 & 33.31 & 700 \\
\hline & Isparta (3rd $z o n e)$ & 37.46 & 30.33 & 1043 \\
\hline & Kırklareli (3 $3^{\text {rd }}$ zone) & 41.44 & 27.12 & 203 \\
\hline \multirow[t]{4}{*}{$4^{\text {th }} \mathrm{DDR}$} & Ardahan ( $4^{\text {th }}$ zone) & 41.07 & 42.41 & 2200 \\
\hline & Erzurum (4 ${ }^{\text {th }}$ zone) & 39.55 & 41.17 & 1893 \\
\hline & Kayseri (4th $z o n e)$ & 38.43 & 35.30 & 1071 \\
\hline & Hakkari ( $4^{\text {th }}$ zone) & 37.34 & 43.45 & 1720 \\
\hline
\end{tabular}
$\mathrm{C}$ and calculated solar radiation values belong to the cities located at high latitudes, especially over $39^{\circ} \mathrm{N}$

Table 1. Latitude, longitude and altitude of the cities considered in this study 

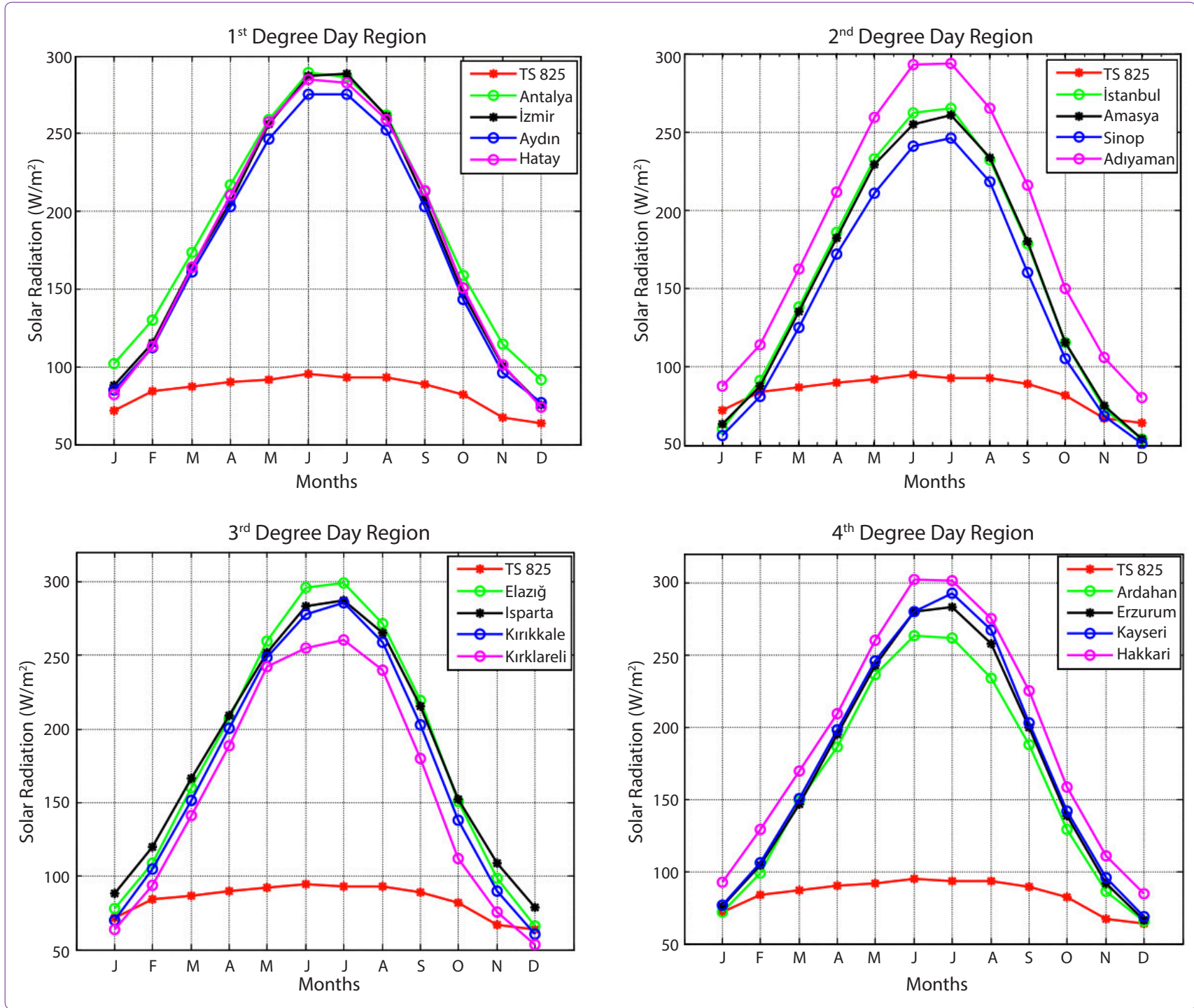

Figure 2. Comparison of calculated and Appendix-C values of solar radiation for horizontal surfaces.

(for ex. Amasya, Ardahan, Erzurum, Kırıkkale, Sinop). Appendix-C proposes average values of solar energy for all Turkey and the cities over $39^{\circ} \mathrm{N}$ has solar potential close to this average values. But the cities located under $39^{\circ} \mathrm{N}$ latitude has much more solar energy potential. Necessarily marked results are seen when the calculated values are compared with the table values. Although the results differ from city to city, the maximum errors for all cities are in a range of $60-70 \%$. This difference cannot be ignored during the calculation and design process.

South openings play an important role in a building's heat balance. South faced windows gives solar heat an opportunity to penetrate indoors by solar radiation, which hits the earth surface at a shallow angle in winter season. Oppose to this in summer period when the solar rays hit the earth surface at a steep angle, this prevents south surfaces from excessive solar gains. This characteristic helps designers to construct energy efficient buildings. Appropriate window design on this facade helps to reduce the energy consumption both for heating and cooling.

The comparison of the calculated monthly average solar radiation with the Appendix $C$ values for southoriented windows is given in Figure 3 . For each of the DDRs, the solar radiation on this direction is much lower than the calculated values, which are based on the real sunshine duration data from the cities considered. The maximum solar radiation difference between the calculated and table values of south surfaces varied between 42.03\% (Aydın) and 53.29\% (Antalya) for $1^{\text {st }}$ DDR, $28.4 \%$ (Sinop) and $49.32 \%$ (Adıyaman) for $2^{\text {nd }}$ 
Table 2. The maximum and minimum errors between the calculated and proposed solar radiation values given in Appendix-C for the 16 cities

\begin{tabular}{|c|c|c|c|c|c|c|c|c|c|}
\hline \multirow[t]{2}{*}{ DDR } & \multirow[t]{2}{*}{ Province } & \multicolumn{2}{|c|}{ Horizontal } & \multicolumn{2}{|c|}{ South } & \multicolumn{2}{|c|}{ North } & \multicolumn{2}{|c|}{ East-West } \\
\hline & & $\begin{array}{c}\min (\%) \\
\text { error }\end{array}$ & $\begin{array}{c}\max (\%) \\
\text { error }\end{array}$ & $\begin{array}{c}\min (\%) \\
\text { error }\end{array}$ & $\begin{array}{c}\max (\%) \\
\text { error }\end{array}$ & $\begin{array}{c}\min (\%) \\
\text { error }\end{array}$ & $\begin{array}{c}\max (\%) \\
\text { error }\end{array}$ & $\begin{array}{c}\min (\%) \\
\text { error }\end{array}$ & $\begin{array}{c}\max (\%) \\
\text { error }\end{array}$ \\
\hline \multirow[t]{4}{*}{$1^{\text {st }} \mathrm{DDR}$} & Antalya & 29.48 & 67.16 & 3.56 & 53.29 & 0.24 & 16.67 & 20.60 & 37.19 \\
\hline & Aydın & 15.39 & 66.20 & 9.97 & 42.03 & -0.38 & 14.22 & 9.65 & 30.10 \\
\hline & Hatay & 12.06 & 67.11 & 2.77 & 44.58 & 1.54 & 9.43 & 4.91 & 33.04 \\
\hline & Izmir & 15.20 & 67.76 & 7.33 & 47.21 & -1.93 & 16.34 & 12.05 & 32.12 \\
\hline \multirow[t]{4}{*}{$2^{\text {nd }} D D R$} & Istanbul & 8.05 & 64.93 & -1.30 & 35.40 & -1.43 & -22.03 & 0.54 & -29.26 \\
\hline & Amasya & 4.60 & 64.32 & -3.22 & 35.00 & -2.53 & -20.10 & 1.01 & -30.49 \\
\hline & Sinop & 2.61 & 62.25 & -0.17 & 28.40 & 4.82 & -30.06 & 4.19 & -40.42 \\
\hline & Adıyaman & 18.26 & 68.33 & 6.53 & 49.32 & -0.07 & 17.59 & 12.40 & 34.59 \\
\hline \multirow[t]{4}{*}{$3^{\text {rd }}$ DDR } & Elazığ & 7.68 & 68.92 & 9.30 & 47.59 & -1.74 & 17.92 & 1.09 & 35.99 \\
\hline & Isparta & 18.71 & 67.66 & 4.77 & 51.01 & 0.25 & 15.77 & 13.52 & 33.78 \\
\hline & Kırıkkale & 3.03 & 67.45 & 8.25 & 43.11 & -1.03 & -14.79 & 4.89 & 31.37 \\
\hline & Kırklareli & 11.57 & 64.28 & -2.17 & 36.63 & 0.66 & -22.15 & 4.88 & -31.18 \\
\hline \multirow[t]{4}{*}{$4^{\text {th }} \mathrm{DDR}$} & Ardahan & 0.63 & 64.46 & 8.55 & 41.24 & -0.51 & -18.61 & 0.60 & 23.30 \\
\hline & Erzurum & 3.31 & 67.11 & 8.85 & 43.65 & 0.41 & 14.66 & -1.65 & 28.65 \\
\hline & Kayseri & 5.75 & 68.24 & 6.27 & 43.72 & -3.24 & 14.83 & -1.25 & 30.89 \\
\hline & Hakkari & 22.22 & 69.15 & 7.70 & 52.08 & -2.18 & 19.15 & 20.52 & 37.21 \\
\hline
\end{tabular}
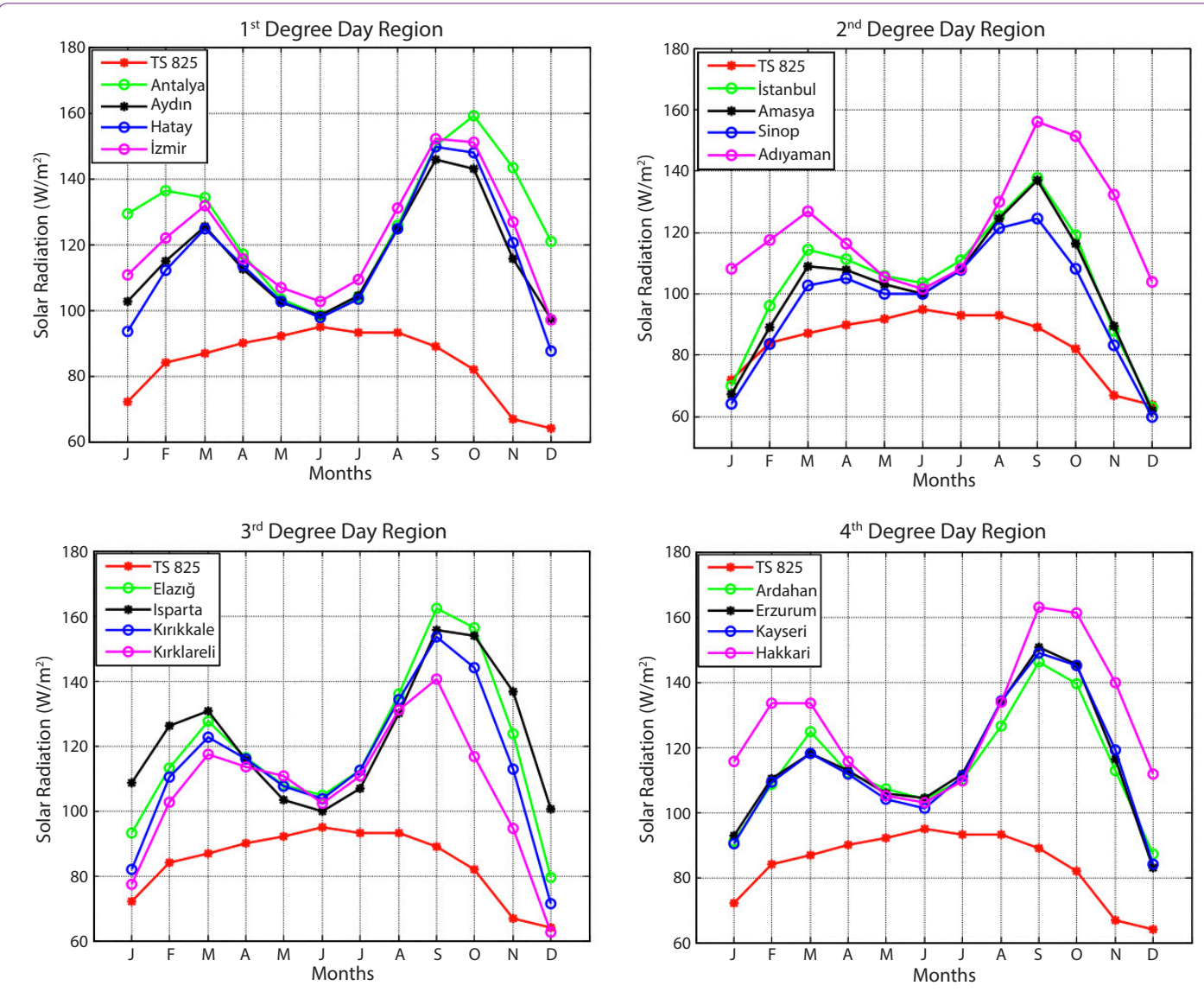

Figure 3. Comparison of calculated and Appendix-C values of solar radiation for south faced surfaces. 
DDR, 36.64\% (Kırklareli) and 51.0\% (Isparta) for $3^{\text {rd }}$ and 41.25\% (Ardahan) and $52.08 \%$ (Hakkari) for the $4^{\text {th }}$ DDR as given in Table 2. Such a big amount of diversity makes designers and engineers make errors in the calculation of building energy needs. By considering the Figure 3 , it is seen that in May, June and July period the calculated and table values of solar radiation are fairly close to each other. The usage of the table values will not cause a considerable mistake. But for the times except these months, the solar radiation values of TS 825 Appendix$C$ for south oriented windows are inappropriate.

North openings are ineffective in solar heat gains of buildings. These facades don't receive direct solar radiation except sunrise and sunset hours during the day. Excluding these hours the radiation on north surfaces is the sum of the diffuse and reflected components. North and north-east directions are important for providing natural illumination. But while providing visual comfort the indoor thermal comfort must be considered. Because the solar gains in winter are very poor when compared with the heat losses through the windows. When the calculated and the table values for this direction are compared (Figure 4), it is seen that they show the same behavior during the year except the summer period (especially in May, June and July) for all of the DDRs. The main reason of this case is the increasing of solar radiation on east and west directions due to the incidence angle of solar rays. The average differences for May are $1.34 \%, 3.26 \%, 1.49 \%$ and $0.87 \%$ for DDRs from 1 to 4 respectively. The average differences for June are $15.75 \%$, $10.82 \%, 14.23 \%$ and $14.88 \%$ for the DDRs from 1 to 4 . For July, the calculated and table values differs on average $9.49 \%$ for the $1^{\text {st }}, 8.07 \%$ for $2^{\text {nd }}, 10.70 \%$ for the $3^{\text {rd }}$ and $10.91 \%$ for the $4^{\text {th }}$ DDR.
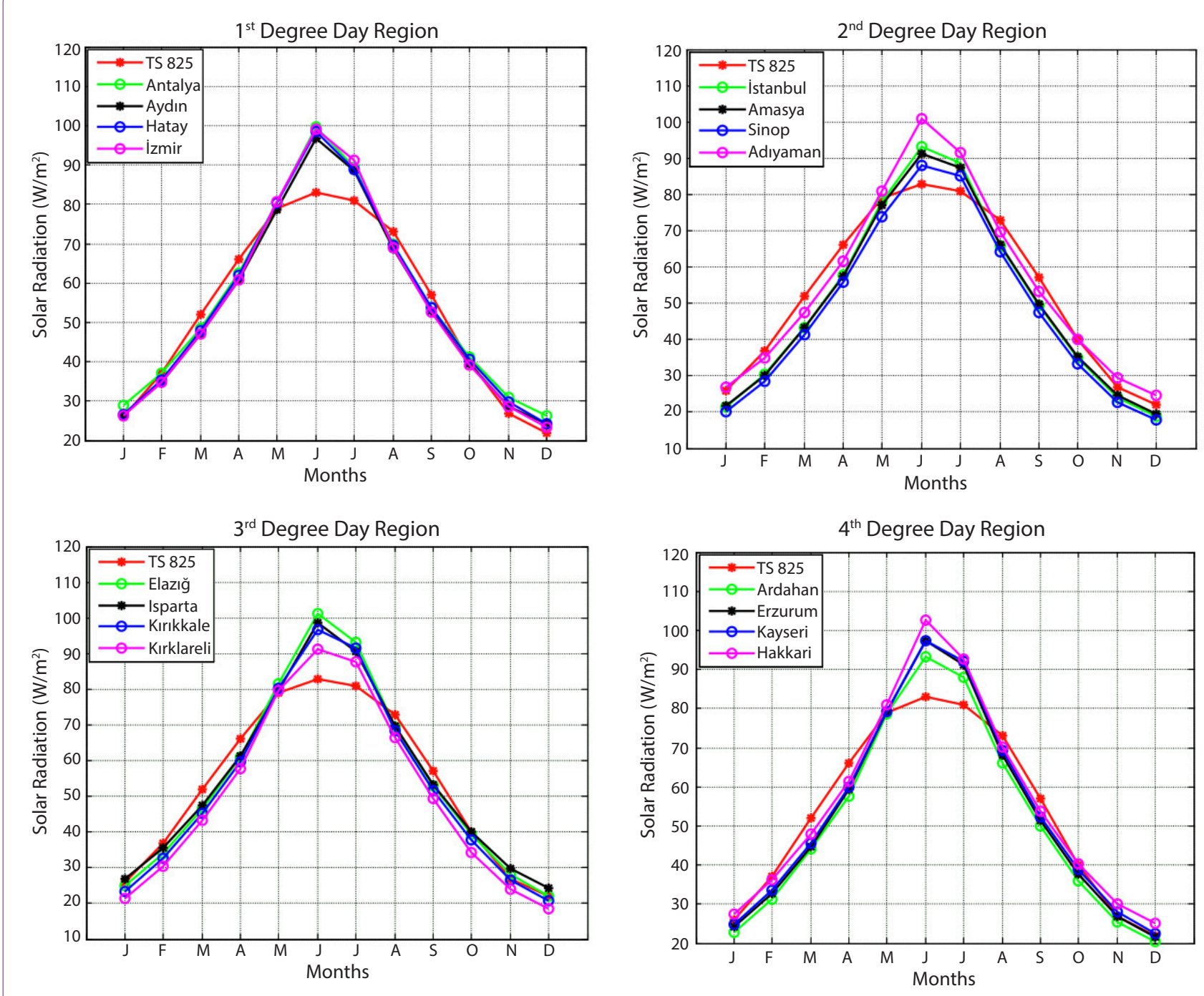

Figure 4. Comparison of calculated and Appendix-C values of solar radiation for north faced surfaces 
Windows on east and west facades are very similar and not as effective as south facades in reducing the buildings heating energy requirements in heating period. Because long nights and short daytime, prevent these surfaces from warming up. However in summer the solar radiations on these directions are one of the most important factors in determining the buildings cooling requirements. With the arrival of sunrays directly to the earth surface, they begin to work as a heat source in this direction. Finally, in summer season they become one of the major causes of a building's cooling requirements. Increase of building average temperature due to long daylight hours causes especially the west oriented windows to be in sunset hours because of the intense solar radiation on this direction. The east and west directions generally take the same amount of radiation during the day. So, their solar behavior during the year is given together in Figure 5. TS 825's Appendix-C values for all regions are quite lower than the surface's actual solar radiation potential. This will cause the designers to be unaware of the large cooling load potential of these surfaces, especially from May to October. This situation is clarified by, emphasizing the amount of the differences between the calculated and table values. For the $1^{\text {st }} D D R$, the difference between the calculated and table values varies between $4.91 \%$ and $37.19 \%$ for the $1{ }^{\text {st }}, 0.54 \%$ and $40.42 \%$ for the $2^{\text {nd }}, 1.09 \%$ and $35.99 \%$ for the $3^{\text {rd }}$, and $0.60 \%$ and $37.21 \%$ for the $4^{\text {th }}$ DDRs.

The maximum and minimum errors between the calculated solar radiation and Appendix- $C$ are given in Table 2. Table indicates that the biggest differences belong to the south and east-west facades. These di-
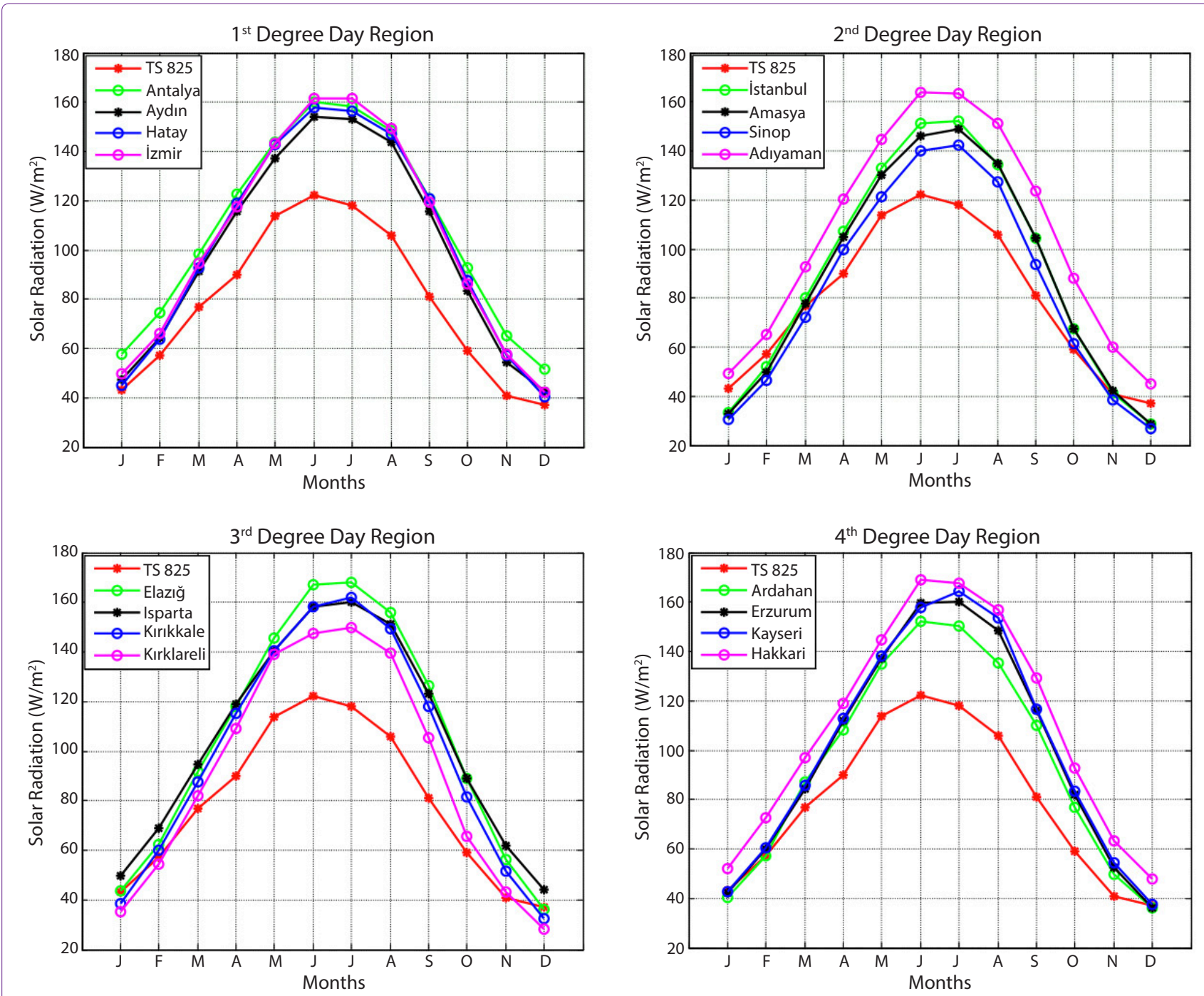

Figure 5. Comparison of calculated and Appendix-C values of solar radiation for east-west faced surfaces. 
rections are the main contributors for decreasing the heating energy requirement in winter and for increasing the cooling demand of buildings in summer period. The accuracy of the calculation of a building's energy requirements is directly proportional to the accuracy of the reference solar radiation data.

In addition to the solar radiation table, the ambient temperature table used in calculating heating energy needs must be evaluated. The comparison of the proposed ambient temperature of the four DDRs in TS 825 with the actual long-term average values (between 1990 and 2012) is given in Figure 6. As it is seen from the figure, the proposed temperatures in TS 825 only match with the $1^{\text {st }}$ DDR's ambient temperatures and can be used in calculations. The ambient temperatures given in TS 825 for the $2^{\text {nd }}, 3^{\text {rd }}$ and $4^{\text {th }}$ DDRs must be investigated too.

\section{Conclusion}

In this study, the appropriateness of the widely used solar radiation table given in Appendix-C of TS 825 Thermal Insulation Requirements in Buildings Standard for different DDRs is investigated. The results obtained in this study demonstrate that appendix-C of TS 825 is not appropriate for determining the solar heat gains of windows. Standard recommends the usage of average solar radiation data for all directions by neglecting the geographical (latitute, altitude...) position and climatic conditions. This average values can be appropriate over $39^{\circ} \mathrm{N}$ latitude but for the locations under $39^{\circ} \mathrm{N}$ the table values are far removed from the calculated solar radiation with the real climatic data.

In conclusion, the usage of Appendix-C table of TS 825 is not recommended in determining the solar heat gain of buildings in Turkey. Solar radiation can be ob-

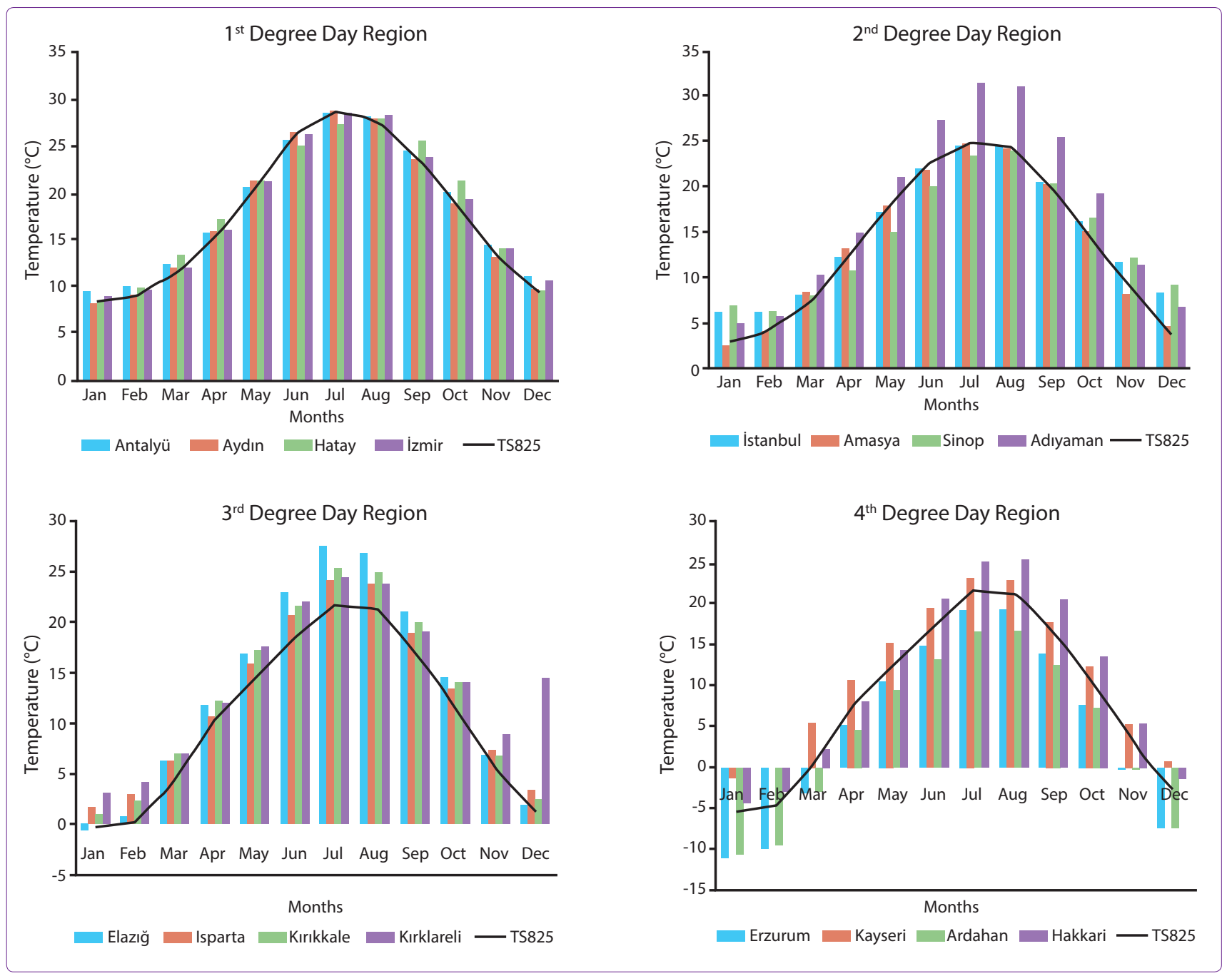

Figure 6. Comparison of the proposed ambient temperatures in TS 825 with the actual long term averages for the selected cities for each of the degree day regions. 
tained by measurements. However the measurement devices are very expensive so, it is hard to install and maintain a measurement station. Finally the solutions prescribed by BEP must be considered or the table values must be calculated for every location with the appropriate regional climatic and geographical data.

\section{References}

1. Lam JC, Li DHW. Correlation Between Global Solar Radiation and its Direct and Diffuse Components. Building and Environment 1996;31:527-535.

2. Sànchez de la Flor FJ, Cebolla RO, Félix JLM, Dominguez SA. Solar Radiation Calculation Methodology for Building Exterior Surfaces. Solar Energy 2005;79:513-522.

3. Kassem MA, Kaseb S, El-Refai MF. Solar Heat Gain Through Vertical Cylindrical Glass. Building and Environment 1999;34:253-262.

4. Sözen A, Arcaklıoğlu E, Özalp M. Estimation of Solar Potential in Turkey by Artificial Neural Networks Using Meteorological and Geographical Data. Energy Conversion and Management 2004;45:3033-3052.

5. Aksoy UT, Bektaş Ekici B, TS 825 iklimsel Verilerinin Farklı Derece Gün Bölgeleri için Uygunluğunun Değerlendirilmesi, METU Journal of Faculty of Architecture, 2013;30(2):2013.

6. Durmaz AF, Eğik Yüzeylere Gelen Güneş Işınımının Analizi ve Cam Yüzeylerden Geçen Güneş Işınımının Tespiti, Harran Üniversitesi Fen Bilimleri Enstitüsü, 2007.

7. Eke R, Şentürk $A$, Monitoring the Performance of Single and Triple Function Amorphous Silicon Study Modules in Two Building Integrated Photovoltaic (BIPV) Installations, Applied Energy, 109;154-162:2013

8. TS 825, 2008. Thermal Insulation Requirements in Buildings. Turkish Standards Institution. Ankara. Turkey.

9. ASHRAE Handbook Fundamentals, 1997. American Society of Heating. Refrigerating and Air-Conditioning Engineers. ASHRAE, Atlanta, GA.

10.BEP: Energy Performance Regulations in Buildings 01/04/2010.Official gazette of Turkish republic. Number: 27075.

11. Dilmac S, Kesen N. A Comparision of New Turkish Thermal Insulation Standard (TS 825). ISO 9164. EN 832 and German Regulation. Energy and Buildings 2003;35:161174.

12. Bektas Ekici B, Aytac Gülten A, Aksoy UT. A study on the Optimum Insulation Thicknesses of Various Types of External Walls with Respect to Different Materials Fuels and climate Zones in Turkey. Applied Energy 2012;92:211217.

13. Ozkan DB, Onan C. Optimization of Insulation Thickness for Different Glazing Areas in Buildings for Various Climatic Regions in Turkey. Applied Energy 2011;88:1331134.

14. Bolattürk A. Optimum Insulation Thicknesses for Building Walls with Respect to Cooling and Heating Degree-Hours in the Warmest Zone of Turkey. Building and Environment 2008;43:1055-1064.
15. Sisman N, Kahya E, Aras N, Aras H. Determination of Optimum Insulation Thicknesses of the External Walls and Roof (ceiling) for Turkey's Different Degree-day Regions. Energy Policy 2007;35:5151-5155.

16. Comaklı K, Yuksel B. Optimum Insulation Thickness of External Walls for Energy Saving. Applied Thermal Engineering 2003;23:473-479.

17. Dombaycı ÖA. The Environmental Impact of Optimum Insulation Thickness for External Walls of Buildings. Building and Environment 2007;42:3855-3859.

18. Bulut H, Büyükalaca O. Simple Model for the Generation of Daily Global Solar-Radiation Data in Turkey. Applied Energy 2007;84:477-491.

19. Bulut H, Durmaz AF, Yeşilata B. Eğik Yüzeye Gelen Güneş Işınımı Değerlerinin Deneysel Olarak Incelenmesi. Proceedings of UGHEK'2006: I. Ulusal guneş ve hidrojen enerjisi kongresi 2006:143-149, Eskişehir.

20. Togrul IT, Togrul H, Evin D. Estimation of Global Solar Radiation Under Clear Sky Radiation in Turkey. Renewable Energy 2000;21:271-287.

21. Senkal O, Kuleli T. Estimation of Solar Radiation over Turkey Using Artificial Neural Network and Satellite data. Applied Energy 2009;86:1222-1228.

22. Angstorm A, Solar and Terrestrial Radiation Report to the International Commission for Solar Research on Actinometric Investigations of Solar and Atmospheric Radiation. Quarterly Journal of the Royal Meteorological Society, 1924;50:121-126.

23. Prescott J.A., Evaporation from a Water Surface in Relation to Solar Radiation, Transactions and Proceedings of the Royal Society of South Australia,1940;64:114-148, 1940.

24. Hay JE, Calculation of Monthly Mean Solar Radiation for Horizontal and Inclined Surfaces. Solar Energy, 1979;23:301-307.

25. Gueymard CA, An Anisotropic Solar Irradiance Model for Tilted Surfaces and its Comparison with Selected Engineering Algorithms. Solar Energy, 1987;38:367-386.

26. Perez R, Ineichen P, Seals R, Michalsky J, Stewart R,. Modeling Daylight Availability and Irradiance Components from Direct and Global Irradiance, Solar Energy, 1990;44:271-289.

27. Berköz, E, Güneş Işınımı ve Yapı Dizaynı, Profesörlük Tezi, İstanbul Teknik Üniversitesi Baskı Atölyesi İstanbul, 1983.

28. Aksoy UT, The Effect of Building Orientation and Shaping on the Cost of Heating from the Aspect of Climatic Comfort. PhD Thesis, Firat University Institute of Sciences, Turkey, 2002.

29. Mediavilla MD, Miguel AD, Bilbao J. Measurement and Comparison of Diffuse Solar Irradiance Models on Inclined Surfaces in Valladolid (Spain). Energy Conversion and Management 2000;46:2075-2092.

30. Gueymard C. Predicting and Performance Assessment of Mean Hourly Global Solar Radiation. Solar Energy 2000; 68:285-303.

31. Li DHW, Lam JC, Lau CCS. A New Approach for Predicting Vertical Global Solar Irradiance. Renewable Energy 2002;25:591-606. 
32. Duffie JA, Beckmann WA. Solar Engineering of Thermal Processes. Second ed. (1991) John Wiley \& Sons Inc, New York.

33. Liu BHY, Jordan RC. Daily Insolation on Surfaces tilted Towards the Equator. Trans. ASHRAE 1962:526-541.

34. Aksoy UT, Inallı M. Impacts of Some Building Passive Design Parameters on Heating Demand for a Cold Region. Building and Environment 2006;41:1742-1754.

35. Notton G, Cristofari C, Poggi P. Performance Evaluation of Various Hourly Slope Irradiation Models Using Mediter- ranean Experimental Data of Ajaccio. Energy Conversion and Management 2006;47:47-173.

36. Ma CCY, Iqbal M, Statistical Comparison of Models for Estimating Solar Radiation on Inclined Surfaces. Solar Energy 1983;31:313-317.

Key words: Orientation; solar heat gain; solar radiation; window; TS 825.

Anahtar sözcükler: Yönlenme; güneş ısısı kazancı; güneş ışınımı; pencere; TS 825. 